\title{
Renewable Energy Policies and Competition for Biomass: Implications for Land Use, Food Prices, and Processing Industry
}

\begin{abstract}
We use a mathematical programming model to examine the impacts of simultaneous implementation of two US biofuel and bioenergy policies on commodity markets and spatial distribution of future cellulosic biorefineries. The key findings based on our numerical simulation are: 1) the number and average annual production capacity of cellulosic biofuel refineries depend on the total renewable fuels mandate; 2) the mix of cellulosic biomass feedstock depends on the assumptions about the production costs of energy crops and the amount of cropland that can be used for energy crops, but regardless of the assumptions crop residues are the primary biomass source to meet the demand for biomass for biofuel production and electricity generation; and 3) the biomass production areas would surround either future cellulosic biorefineries or the existing coal-based power plants to reduce the costs of biomass transportation. These findings have important implications for biorefinery investors and provide valuable policy insights for the selection of Biomass Crop Assistance Program project areas.
\end{abstract}

Keywords: biofuel and bioenergy policies; cellulosic biorefinery; food prices; crop residues; energy crops 


\section{Introduction}

Concerns about air quality, energy security, and global climate change have led to several regulatory policies in the United States (US) to promote the production of renewable energy and displace fossil fuel consumption. To reduce oil-based fossil fuel consumption in the transportation sector, the Energy Independence and Security Act (EISA) of 2007 established the Renewable Fuel Standard (RFS) (hereafter referred to as EISA-RFS), which mandates blending 136 billion liters of renewable fuels with oil-based transportation fuels by 2022. Besides the total amount, specific blending targets are imposed for different types of biofuels based on their lifecycle greenhouse gas (GHG) performances. Specifically, 79 billion liters of the total amount must be 'advanced' biofuels that reduce GHG emissions by more than $50 \%$ relative to the conventional fuels they replace, of which at least 61 billion liters must be produced from cellulosic biomass. To mitigate the adverse impact of biofuel production on food prices, the EISA-RFS also requires that the amount of corn ethanol used to meet the mandates cannot exceed 57 billion liters. However, due to the slow development of the cellulosic biofuel industry, the mandated volumes of cellulosic biofuels are considered unlikely to be achieved by 2022 . The Annual Energy Outlook (AEO) of 2015 (EIA, 2015a) projects that the production of renewable fuels will be about 64 billion liters (ethanol energy equivalent) in 2022 (hereafter referred to as AEO-RFS), consisting of 57 billion liters of corn ethanol and 7 billion liters of advanced (nonstarch) biofuels and biodiesels derived from vegetable oils ${ }^{1}$.

\footnotetext{
${ }^{1}$ In addition to the RFS, a state-wide Low Carbon Fuel Standard (LCFS) has been established in California, which requires a $10 \%$ reduction in the GHG intensity of transportation fuels sold in the state by 2020 . By requiring blending low-carbon biofuels into oil-based transportation fuels, the LCFS may increase the quantity of biofuels used in California, but it will not affect the aggregate quantity of biofuels consumed in the US. That is because the increase in biofuels in California will be fully offset by reduced biofuel consumption in other US states Schatzki, T., Stavins, R.N., 2012. Implications of Policy Interactions for California's Climate Policy. http://papers.ssrn.com/sol3/papers.cfm?abstract_id=2296024..
} 
In 2014, the US corn ethanol industry reached a total production capacity of 54.3 billion liters (RFA, 2014), which is close to the limit envisioned by the RFS. To meet the targets for advanced biofuels specified by the RFS, the US can import sugarcane ethanol from Brazil and/or produce cellulosic biofuels domestically. Although historically Brazil was the main exporter of ethanol to the US, this trend has been reversed in recent years due to the growing domestic demand for ethanol in Brazil and also due to the shortages in ethanol supply in Brazil. Therefore, most of the future biorefineries will have to produce cellulose-based advanced biofuels to meet the RFS targets.

In the electricity sector, Renewable Portfolio Standards (RPS) in various forms have been adopted by 35 states and the District of Columbia. Different from the RFS, the RPSs are statelevel regulations that require increased production of electricity from renewable sources, such as hydropower, wind, solar, biomass, and geothermal energy. Of the 36 states adopting RPS, 31 states impose RPS as mandatory targets, while the other 5 states set RPS as voluntary targets (Davies, 2010). To reduce the cost of meeting the RPS regulations, federal tax support, mainly in the form of tax credits and accelerated depreciation rates, for renewable energy projects has been provided (Mormann, 2014a). As compared to other renewable energy sources, utility-scale solar and wind power have become increasingly cost-competitive in recent years (Lazard, 2014). However, biomass cofiring is still considered as a near-term and low-cost approach to incorporate biomass into today's energy mix relative to dedicated biomass power plants (AlMansour and Zuwala, 2010; Sebastián et al., 2011). In fact, biomass cofiring has been adopted by many existing coal power plants to generate power in order to meet state-level RPS regulations (EIA, 2012). The AEO projects that about 59 billion kilowatt-hours of electricity 
would be generated from biomass by 2040 , accounting for about $2.6 \%$ of the total electricity production in that year (EIA, 2015a).

Given that the total amount of cellulosic biomass demand to meet the RFS and RPS regulations is substantial, implementation of these two policies simultaneously will require diverting a large amount of cropland from food/feed crops to biomass production. This may have significant impacts on traditional agricultural commodity markets and land allocation among food and biofuel crops. The concurrent implementation of the two policies will also create a competition for cellulosic biomass between coal-fired power plants and future cellulosic biorefineries, and thus will impact the spatial distribution of the biofuel processing facilities. Economic viability of a cellulosic biorefinery depends on the availability of a sufficient and sustainable local feedstock supply and low procurement costs. Conversely, besides comparative advantage in producing biomass crops vis-à-vis conventional food/feed crops, economic viability of regional biomass supply depends on the proximity to biofuel processing facilities and coalbased power plants. Therefore, strategic planning for future cellulosic biorefinery industry and renewable energy generation has to take all these factors into account in a unified framework.

The purpose of this paper is two-fold. First, we determine regional cellulosic biomass supply pattern and optimal locations of future biorefineries in response to the RFS and RPS provisions. Second, we examine the impacts of the concurrent implementation of the RFS and RPS on agricultural commodity markets, namely production, consumption, and prices of multiple food and feed crops. We address these issues under the AEO-RFS and RPS, and compare the results with those obtained under the EISA-RFS and RPS. We also analyze a third policy scenario that considers reduced RFS mandated levels of cellulosic biofuel production and a plausible level of electricity generation from cellulosic biomass based on the observed electricity produced from 
biomass in recent years. We also conduct a variety of robustness checks to examine the sensitivity of our results to variations in key model parameters, in particular the production costs and yields of cellulosic biomass.

Previous studies in the literature have examined economic and environmental impacts of the RPS and the RFS in isolation (Ando et al., 2010; Beach and McCarl, 2010; Chen and Önal, 2012; de Gorter and Just, 2009; Fischer, 2010; Hertel et al., 2010; Hudiburg et al., 2016; Nogee et al., 2007). A few studies have addressed the biofuel infrastructure required to meet the biofuel mandates (Chen and Önal, 2014; Parker, 2012). Surprisingly, no published study has examined the impacts of concurrent implementation of the two policies on US agricultural commodity markets and the bioenergy/biofuel industries considering the logistics and supply chain network.

The rest of the paper is organized as follows. In Section 2, we describe the model used in the numerical simulations and the underlying key assumptions, followed by description of data sources in Section 3. We present main simulation results in Section 4. Section 5 concludes and provides policy implications of the results.

\section{Methodology}

The numerical simulation model used in the analysis is a multi-market, multi-period, priceendogenous, nonlinear mathematical programming model, called Biofuel and Environmental Policy Analysis Model (BEPAM). The model integrates the agricultural and transportation fuel sectors in the US and incorporates international trade of agricultural commodities, conventional fuels and biofuels with the rest of the world (ROW). The agricultural sector of BEPAM considers markets for primary and processed crop commodities, livestock products, and cellulosic biomass for biofuel and bio-power production, while the transportation fuel sector 
includes markets for several first- and second- generation biofuels. The key endogenous variables in the model are domestic consumption and trade of food/feed commodities and fuels, and regional land allocation among various food/feed/fuel crops and livestock over time. The market equilibrium is determined by maximizing the sum of consumers' and producers' surpluses in the transportation and agricultural sectors subject to market clearing conditions, resource availability constraints, and policy restrictions, assuming that fuel and agricultural markets are perfectly competitive. For a detailed discussion of this methodology, see McCarl and Spreen (1980) and Takayama and Judge (1971).

BEPAM has been previously used to analyze the impacts of various biofuel and climate policies (Chen et al., 2014; Chen and Önal, 2012; Huang et al., 2013). The present study extends BEPAM by adding a facility location and supply chain component for cellulosic biomass to simultaneously determine the locations of future biofuel processing facilities, regional feedstock supply response, and delivery of biomass to biofuel processing facilities and coal-fired power plants to meet the respective biofuel and bioenergy targets. The extended version of BEPAM with the supply chain and facility location component is highly complex. For the sake of readability, we present the details of the mathematical model in the appendix.

\section{Model specification and data}

The empirical model includes fifteen conventional crops, eight livestock products, various processed crop and livestock products, and two dedicated energy crops as well as crop and forest residues as cellulosic biomass (see Table 1). Primary crops can be consumed domestically and/or traded with the ROW, processed to final products, or fed to livestock animals. Domestic and export demands and import supplies are incorporated by assuming linear price-responsive 
demand/supply functions. These domestic and export demand functions are shifted upward over time at exogenously specified rates.

The model includes 3,122 counties in 41 US states in five major regions, and considers each county as a decision unit for crop and livestock production. Each county is assumed to be represented by a rational producer who allocates available production resources among a specified set of production activities to maximize the total net returns from producing various crop and livestock products. Row crops can be produced in various rotations with other row crops (such as continuous corn, corn-soybean, fallow-wheat).

Land is the only limited resource endowment considered in the model, while other inputs for crop and livestock production can be obtained at fixed market prices. The model includes cropland, idle land, cropland pasture, pasture land and forestland pasture. Idle land and cropland pasture can be converted to the production of conventional and energy crops at a conversion cost. We keep the land under pasture land and forestland pasture unchanged over the planning horizon due to the high costs of conversion (including land clearing, wind rowing and any necessary activities for seedbed preparation) and large stocks of carbon stored under the two land covers.

The model includes demand for VKT with five types of vehicles, including conventional gasoline, flex fuel, gasoline-hybrid, diesel vehicles, and plug-in and battery electric vehicles. The VKT production function considers the energy content of transportation fuels, fuel economy of each type of vehicle, and technological limits on blending fossil fuels and biofuels for each of these four types of vehicles. Demand curves for VKT are exogenously shifted over time as projected by the Annual Energy Outlook 2015 (EIA, 2015a), to capture the growth in demand due to changes in vehicle fleet, income and population. We include linear supply curves for domestic gasoline and diesel as well as for gasoline supply and demand in the ROW. Exports of 
gasoline from the ROW to the US are determined by the difference between gasoline demand and supply in the ROW. Diesel is assumed to be produced domestically.

The biofuel sector includes several first- and second-generation biofuels. First-generation biofuels include corn ethanol, biodiesel derived from vegetable oils, and imported sugarcane ethanol. Second-generation biofuels are produced from cellulosic biomass that can be converted to either lignocellulosic ethanol or biomass-to-liquid (BTL). The feedstock costs of biofuels consist of two components: a cost of producing the feedstock which includes costs of agricultural inputs and field operations, and a cost of land. The former is calculated at county level for each crop, while the costs of land at regional level are endogenously determined by the shadow prices of the land constraints (8) in the model. The costs of processing biofuels are assumed to decline over time due to learning-by-doing (Chen et al., 2012; de Witt et al., 2010). This relationship is represented as $Y=a X^{b}$, where $Y$ is the unit cost of production, $X$ is the cumulative production, $a$ is the initial production cost per unit, and $b$ is a constant capturing the rate of cost reduction. The initial biofuel conversion costs and experience indexes are obtained from Chen et al. (2014).

We calibrate the domestic and export demand functions and import supply functions for agricultural commodities based on the observed prices and quantities in 2007. The VKT demand for different types of vehicles, ROW gasoline demand, and supply of gasoline and diesel are also calibrated using the corresponding observed fuel prices and quantities in 2007. The elasticities used to calibrate these demand and supply functions are obtained from Chen et al. (2014).

The county-level resource availability, crop production costs, and crop yields are compiled from various agricultural experiment stations and the USDA-NASS database (2010). Yields and production costs of crop residues and energy crops differ across regions. Crop residue yields for each county are obtained based on grain-to-residue ratio of dry matter of crop grain to dry matter 
of crop residues and the moisture content in the grain (Graham et al., 2007; Sheehan et al., 2003), and residues collection rates depend on tillage practices (Malcolm, 2008). The costs of producing crop residues include the additional cost of fertilizer that needs to be applied to replace the loss of nutrients and soil organic matter due to the removal of crop residues from the soil, and the costs of harvesting and storage. We obtain the regional supply of forest residues from California Air Resources Board ${ }^{2}$.

The yields of perennial energy crops and the production costs throughout their lifetime are based on Jain et al. (2010). The production costs of bioenergy crops include the establishment costs in the first year and the costs related to harvesting, storage and transportation in subsequent years. Existing studies vary in their assumptions about input requirements, pre-harvesting, harvesting and storage costs. To address these uncertainties we construct an optimistic scenario and a pessimistic scenario. The optimistic scenario assumes a low fertilizer application rate, low replanting probability, high second-year yield, low harvest loss, and low harvesting costs. The pessimistic scenario considers the opposite of all these, as described in Jain et al (2010). Both yields and costs of production are assumed to be the same on marginal lands and regular cropland (see Table 2).

The regional ethanol demands are specified exogenously based on the locations and the total transportation fuel consumption in metropolitan statistical areas (MSAs). For each year of the study period, ethanol consumption is allocated between MSAs in proportion to their base-year fuel consumption. As an approximation we treat the centroid of each county both as an origin and destination of all types of freight, and compute the transportation costs for crops, biomass, and ethanol based on the highway and railroad network (Bureau of Transportation Statistics

\footnotetext{
${ }^{2}$ Available at: http://www.arb.ca.gov/fuels/lcfs/0304091cfs isor vol1.pdf.
} 
2011). The refinery costs for ethanol plants include a fixed investment cost, a variable processing cost proportional to the capacity actually utilized, and an operational cost proportional to the installed refinery capacity, and the cost data are taken from the recent report by the USDOE (2015). The minimum and maximum processing capacities of all potential cellulosic ethanol refineries are specified at 90 and 380 million liters, respectively. We obtain the spatial distribution and installed production capacities of the existing coal-fired power plants from the EIA (2012). We do not consider the possibility of building large-scale dedicated biomass power plants, because dedicated biomass plants have lower efficiency and higher input costs (particularly due to the high transportation cost of biomass) compared to coal power plants (IEA, 2007; Sebastián et al., 2011).

\section{Results and Discussion}

The AEO projects the amount of alternative renewable energy that will be used to meet the RPS mandates over the period 2012-2040 (EIA, 2015a). The share of electricity generated from biomass in total electricity produced using renewable sources is projected to increase from $0.6 \%$ to $2.6 \%$ over this period, with wind, solar power, and hydropower being the primary renewable sources to meet the RPS mandates. We use the AEO projection for the total biomass demand for RPS to set the demand for biomass for electricity generation in the model $\left(\overline{b e}_{t}\right.$ in constraint (31), see the appendix). The AEO projections for RPS-induced biomass demand are given at the national level (rather than at state level). Thus, we state the demand for biomass for electricity generation at the national level. This implicitly implies that bioenergy producers in some states might over-achieve their RPS requirements while others may under-achieve their respective targets. The state-level RPS requirements can be achieved by trading credits between those 
producers. This is a cost-effective way of meeting the RPS and consistent with the reality where some power generating firms operate in multiple states.

We examine the effects of the simultaneous implementation of the AEO-RFS and RPS policies on the US agricultural and transportation fuel sectors, and then compare the results with those obtained under the EISA-RFS combined with RPS. In both cases, we use the AEO projections for RPS-induced biomass demand over the study period. We also examine the impacts of a third policy scenario that extrapolates future cellulosic biofuel and bioenergy production, which we call extrapolated biofuel and bioenergy policies. Specifically, we set the cellulosic ethanol production target at 1.35 billion liters in 2022 , which is $50 \%$ smaller than that projected by the AEO 2015. We extrapolate that the amount of electricity generated from cellulosic biomass in 2022 would be 129 billion kilowatt-hours, which is close to the observed amount of biomass cofired with coal at power plants in 2012 (EIA, 2015b).

When analyzing the three policy scenarios, we focus on: $(i)$ the impacts of these policies on US agricultural commodity markets, (ii) the mix of cellulosic biomass produced to meet the biofuel and bioenergy targets; and (iii) the spatial distribution of future cellulosic refineries and regional biomass feedstock supply. In the baseline analysis presented below, we consider optimistic cost and yield estimates for producing dedicated energy crops. Later we examine the sensitivity of model results to alternative assumptions about these parameters, ease of conversion of land for energy crops, transportation costs of biomass, and the costs of importing sugarcane ethanol. 


\subsection{Impacts of the AEO-RFS and RPS}

To meet the demand for biomass for biofuel production and bioenergy generation as projected by AEO 2015, 26.9 million metric tons (MT) of biomass would be needed in 2022 (Table 3). Of this total amount, 7.3 million MT (27\%) would be used for cellulosic biofuels and 19.5 million MT (73\%) would be used for electricity generation. With an optimistic assumption about the production costs and yields of energy crops, we find that energy crops, crop residues and forest residues will be used for cellulosic biofuel production and for cofiring with coal, accounting for $34 \%, 51 \%$ and $14 \%$ respectively of the total cellulosic biomass production. The model finds that 122.7 million ha of cropland would be cultivated in 2022. Of this, only 0.3 million ha would be allocated to dedicated energy crops, where 0.2 million ha would be converted from marginal lands (due to their lower opportunity costs) and the rest would come from the lands that were previously under food/feed crops. Crop residues would be harvested from 2.0 million ha (1.6 million ha from corn area and 0.4 million ha from wheat area). To induce the required cellulosic biomass production, the average biomass price in 2022 would be $\$ 67.9$ per MT.

Of the 64.0 billion liters of biofuels blended in 2022, about $88 \%$ (56.5 billion liters) would be first-generation biofuels, consisting of 52.7 billion liters of corn ethanol and 3.8 billion liters of biodiesel produced from vegetable oils (all values are in ethanol energy equivalent). About 4.8 billion liters of sugarcane ethanol would be imported in 2022 to meet the domestic demand for biofuels. The high share of corn ethanol is expected due to its low production cost relative to other types of biofuels. The rest of the mandate ( 2.7 billion liters, $4 \%$ ) would be met by cellulosic ethanol. Because of the high industrial processing cost, BTL will not be an economically viable option by 2022. To produce the required amount of cellulosic ethanol, 17 
cellulosic ethanol processing facilities need to be built by 2022 with an average annual production capacity of 158 million liters.

By diverting land from food crops to biofuel crops, the concurrent implementation of the AEO-RFS and RPS policies would increase corn and soybean prices in 2022 by $30 \%$ and $21 \%$, respectively, as compared to the commodity prices that would occur without any biofuel and bioenergy policies, which we call the 'no-policy' scenario. With the large-scale biofuel production in the transportation sector, the GHG emissions in the US agricultural, transportation fuel, and electricity sectors would be 0.3 billion MT smaller as compared to the 'no-policy' scenario over the period 2007-2022. That can be translated into a 2.5 MT reduction in GHG emissions per MT of cellulosic biomass produced, and reducing 1000 MT of GHG emissions would lead to 4.4 ha of land use change by 2022 .

\subsection{Impacts of the EISA-RFS and RPS}

With an ambitious cellulosic biofuel production mandated by the EISA-RFS, the total amount of biomass needed to meet the RFS and RPS targets would be 5.5 times larger compared to the case with the AEO biofuel projections (174.2 million MT versus 26.9 million MT). Most of the additional biomass production would come from crop residues (101.5 million MT, which was 9.2 million MT in the AEO-RFS case), while about one third (57.7 million MT) would be obtained from energy crops. Because of the large increase in the biomass production from energy crops, the land under energy crops would also increase substantially to 4.2 million ha (which was 0.3 million ha under the AEO-RFS scenario). About 70\% (2.9 million ha) of the land under energy crops would come from the conversion of marginal lands. To meet the ambitious 
cellulosic biofuel production target, about 26.0 million ha of land under corn and wheat would be used to collect crop residues in 2022.

The average biomass price in 2022 would be $\$ 91.3$ per MT, which is $34 \%$ higher than the biomass price under the AEO-RFS and RPS policies. The implementation of the EISA-RFS would require 183 cellulosic ethanol processing facilities to produce 56.7 billion liters of cellulosic ethanol by 2022 with an average annual production capacity of 310 million liters (which is $96 \%$ larger than the capacity needed under the AEO-RFS case). By reducing land allocated to food crops, the concurrent implementation of the EISA-RFS and RPS policies would increase corn and soybean prices by about $38 \%$ and $27 \%$, respectively, compared to the 'nopolicy' scenario, which are slightly (7\% and 6\%) higher than the commodity prices under the AEO-RFS and RPS policies. We find that the GHG emissions under the EISA-RFS and RPS scenario would be 0.8 billion MT smaller compared to the 'no-policy' scenario over the period 2007-2022. This is mainly due to the additional use of cellulosic biofuels that displace more fossil fuels in the transportation sector. Under the EISA-RFS and RPS policies, each MT of cellulosic biomass produced can reduce 1.7 MT of GHG emissions over the period 2007-2022, which is significantly smaller than that under the AEO-RFS and RPS policies. This result suggests that for each unit of cellulosic biomass produced, the AEO-RFS and RPS policies are more effective in abating GHG emissions relative to the EISA-RFS and RPS policies. However, to reduce $1000 \mathrm{MT}$ of GHG emissions, the EISA-RFS and RPS policies would require only 2.2 ha of land use change by 2022 , which is $50 \%$ smaller compared to the AEO-RFS and RPS policies. 


\subsection{Impacts of extrapolated biofuel and bioenergy policies}

Under this policy scenario, about 81.7 million MT of cellulosic biomass are expected to be used for cellulosic ethanol and bio-power generation in 2022, which is twice the biomass production level projected by the AEO 2015, but 53\% smaller relative to the level envisioned by the EISA-RFS combined with RPS policies. Of the total cellulosic biomass produced, crop residues, forest residues, and dedicated energy crops would account for 57\% (46.9 million MT), 17\% (14.1 million MT) and 25\% (20.7 million MT), respectively, with the vast majority of the biomass used for electricity generation. About 1.2 million ha of land would be allocated to energy crops in 2022, of which about 1.1 million ha would come from the conversion of marginal lands and the rest comes from the reduction in land under traditional food/feed crops. Of the land under corn and wheat, 10.6 million ha would be used to harvest crop residues in 2022.

To induce cellulosic biomass production, a biomass price of $\$ 78.6$ per MT would be required, which is $16 \%$ higher than the price under the AEO-RFS and RPS policies and 14\% lower than the biomass price under the EISA-RFS and RPS policies. To produce 1.35 billion liters of cellulosic ethanol in 2022, 9 cellulosic ethanol processing facilities would be required, with an average annual production capacity of 150 million liters.

We find that corn and soybean prices under this scenario are similar in magnitude to that under the AEO-RFS and RPS policies, which are 30\% and 19\% higher compared to the "nopolicy' scenario. That is because relative to the AEO-RFS and RPS policies most of the additional cellulosic biomass comes from crop residues that do not compete with food/feed crops for cropland. The total GHG emissions under this scenario would be 0.5 billion MT smaller compared to the 'no-policy' scenario over the period 2007-2022. This implies that each MT of biomass production can reduce GHG emissions by $1.0 \mathrm{MT}$, and that every $1000 \mathrm{MT}$ reductions 
in GHG emissions would lead to a land use change of 5.1 ha.

\subsection{Regional biomass supply and biorefinery locations}

Fig. 1 shows the spatial distribution of cellulosic biofuel processing facilities and regional biomass supply in 2022 under different policy scenarios. Under the AEO-RFS and RPS policies, all future biorefineries would be located in states having comparative advantage in producing energy crops, such as Oklahoma, Texas, Virginia, and Georgia, and located in states with comparative advantage in producing forest residues, such as N. Carolina and S. Carolina (Fig. 1a). Together these states would have 17 cellulosic ethanol facilities and produce 2.7 billion liters of cellulosic ethanol in 2022 .

To meet the cellulosic biofuel production mandated by the EISA-RFS, about 183 cellulosic ethanol processing facilities would be built by 2022 (see Fig. 1b). Several states with large cellulosic ethanol processing facilities under the AEO-RFS, such as Texas, N. Carolina and S. Carolina, would further expand their production capacity. The number of facilities in the three states increases from 10 under the AEO-RFS to 20 under the EISA-RFS. In addition, some other states, especially having comparative advantage in producing crop residues, also build biorefineries to produce the increased amount of cellulosic ethanol. For instance, about 56 refineries would be built in Illinois, Indiana, Missouri and Ohio by 2022 with a total production capacity of 20 billion liters. Under the extrapolated biofuel and bioenergy policy scenario, we

find that the spatial distribution of future cellulosic ethanol facilities is similar to that under the AEO-RFS and RPS policies (see Fig. 1c).

Under the three policy scenarios that we considered, we find that the cellulosic ethanol facilities would be close to the biomass supply regions rather than the blending locations (most 
of which are close to major metropolitan areas which have large fuel demands -therefore large ethanol demands). This is because the cost of shipping biomass from production areas to processing facilities is significantly higher than the cost of distributing ethanol to blending facilities. The biomass production areas surround either the cellulosic biorefineries or the existing coal-based power plants to reduce the cost of biomass transportation (see Fig. 2). These are intuitive and expected results. Another important finding is that to reduce the competition for cellulosic biomass and procurement costs, many cellulosic ethanol facilities would be built away from the regions where the existing coal power plants are located.

\subsection{Sensitivity analysis}

We examine the sensitivity of our results to key assumptions in the model that affect the competitiveness of cellulosic biofuels. Specifically, in Scenario (1), we consider a pessimistic view about the yields and production costs of energy crops. In the baseline case, we impose a $25 \%$ limit on the amount of land that can be converted to energy crops in each county (due to the concerns about adverse impacts of monocultured perennial grasses on biodiversity or sub-surface water flows). In Scenario (2), we reduce this upper limit to $10 \%$ to examine the effects of this assumption on model results. In Scenario (3), we increase the excess supply elasticity of sugarcane ethanol from 2.7 in the baseline to 5.0. In Scenario (4), we increase the unit transportation cost of biomass from supply regions to biorefineries and power plants by $25 \%$ relative to the assumptions made in the baseline scenario. In all scenarios, we change one assumption at a time. We conduct the sensitivity analysis under the AEO-RFS and RPS policies and present some of the key results in Fig. 3. 
Under the pessimistic scenario for costs and yields of perennial energy crops, we find that the amount of energy crops produced would decline by 0.8 million MT relative to the baseline case (Fig. 3a). The demand for biomass would be met mainly by the expansion of land, from 2.0 million ha to 2.3 million ha, from which crop residues are collected. However, because of the upper limit imposed on the amount of corn ethanol used to meet the biofuel mandates, we find that the mix and quantity of biofuels produced are almost identical to those in the baseline case (Fig. 3b).

When the upper limit on the land that can be used to grow energy crops is reduced in each county (Scenario 2) the amount of energy crops production decreases slightly (by 0.2 million MT) relative to the baseline case and the reliance on crop residues for biofuel and bio-power production increases. While the mix of cellulosic feedstocks is altered, the production of cellulosic ethanol remains the same as in the baseline scenario due to high costs of other biofuel alternatives (such as BTL). Under Scenario (3), an elastic supply of imported sugarcane ethanol makes sugarcane ethanol relatively cheaper compared to the baseline scenario. Thus, we observe an increase in sugarcane ethanol import ( 2.2 billion liters) relative to the baseline case and a corresponding reduction in the quantity of corn ethanol and biodiesel to comply with the biofuel mandates.

Under Scenarios (1)-(3), because the target for cellulosic ethanol production is fixed in accordance with the AEO-RFS, we find that the number and average production capacity of cellulosic biorefineries remain similar to that in the baseline case. In contrast, Scenario (4) has limited impacts on the compositions of biofuel and biomass produced; however, this scenario increases the number of biorefineries to 21 (from 17 in the baseline case) in order to reduce the costs of transporting biomass across regions (see Fig. 3c). 
Across the various scenarios that we considered, we find that food prices only differ marginally (see Fig. 3d). This is because collecting crop and forest residues does not cause competition with food/feed crops for cropland and because the vast majority of energy crop production occurs on marginal lands without much impact on the regular cropland use and the production of traditional crop commodities.

\section{Conclusions and Policy Implications}

The impacts of the concurrent implementation of the US bioenergy and biofuel policies on agricultural commodity markets, spatial distribution of future cellulosic biorefineries, and regional supply of biomass highly rely on the targets set for cellulosic biofuels and bio-power production. To meet the EISA-RFS mandate for cellulosic biofuels, the total amount of biomass produced and the number of cellulosic biorefineries required would be ten times larger as compared to the case with the more moderate AEO projections, and twenty times larger if the EPA continues to exercise its waive authority to reduce cellulosic biofuel production target. By diverting more land from food crops to biofuel crops, the implementation of the EISA-RFS and RPS will increase food commodity prices as compared to the AEO-RFS and RPS policies and the extrapolated biofuel and bioenergy policies. The EISA-RFS and RPS can achieve a larger aggregate reduction in US GHG emissions and cause a smaller land use change per unit of GHG abatement relative to other policy scenarios. But the AEO-RFS and RPS outperforms the other two policy scenarios if policy makers' objective is to reduce more GHG emissions for each unit of biomass produced.

Our analysis indicates that the structure of the processing industry (number and size of biorefineries), the mix and quantity of cellulosic biomass and biofuels, and commodity prices 
depend on various factors affecting the regional comparative advantage in energy crop production. For example, in some scenarios we considered here, when energy crops are more costly to produce and the amount of cropland that can be used for energy crops is more limited, crop residues would be the major biomass sources meeting the demand for biomass. Therefore, if our model truly represents the US agricultural production and markets, which depends on the regional costs and yields of crops and various types of biomass, resource availability, and the assumptions made about key parameters used in the model, the current policies putting more emphasis on dedicated energy crops may not be justified.

Several previous empirical studies have examined the biofuel infrastructure required to meet the biofuel mandates (Chen and Önal, 2014; Parker, 2012). By omitting the RPS-induced demand for cellulosic biomass, these studies may have produced biased results on the optimal locations of future cellulosic biorefineries. Our results indicate that to reduce the procurement costs of biomass, it will be cost-effective to locate most of the cellulosic ethanol facilities in regions that have comparative advantages in producing cellulosic biomass and stay away from where most of the existing coal power plants are located. Being the first study examining the impacts of the concurrent implementation of the biofuel and bioenergy policies and considering the logistics and supply chain network, our findings may provide valuable insight to policy makers, agricultural producers, and future cellulosic biofuels industry investors.

Our results may also have important implications for the selection of future Biomass Crop Assistance Program (BCAP) project areas. The BCAP, created in the 2008 Farm Bill, provides subsidies to land owners for the establishment and cultivation of biomass crops for producing heat, power and biofuels. In 2010 alone, about $\$ 243$ million was spent on the program (USDA, 2010). About 173 counties in 10 states have been selected by the BCAP program in 2012, most 
of which are located in the Great Plains and Western states. As the demand for cellulosic biomass increases due to the joint implementation of the RFS and RPS, we can anticipate an increase in the number of those project areas and government spending on the BCAP program over the next decade. Therefore, our model results for the period beyond 2015 can provide useful guidance for the selection of additional future BCAP project areas.

Several caveats should be noted. First, we examine the sensitivity of our results by considering deviations from the key assumptions made in the model one at a time. It is possible that various combinations of these changes might occur simultaneously, resulting in estimated costs of cellulosic biomass being higher or lower than assumed in the model. Second, the model considers land as the only limited resource endowment. However, water might be another constraining factor in regions with insufficient irrigation water and rainfall (Dominguez-Faus et al., 2009). Third, when examining the impacts of the concurrent implementation of the RFS and RPS, we assume full compliance of the mandated cellulosic biofuel production levels over the study period, and ignore that the EPA may allow obligated parties to bank and carry deficit into the following compliance year. Similarly, we have also overestimated the market efficiency of Renewable Energy Certificates (REC) markets by not considering the lack of liquidity of trading in the renewable energy markets (Berendt, 2006; Mormann, 2014b; Wiser et al., 2007). Finally, our simulation model is calibrated using the economic and physical data observed in 2007. Although the current agricultural production and market conditions are quite different, the main conclusions and directions of changes in the model results are likely to remain the same if we used an updated data base. This is because the same economic data base would be used in the baseline case and the alternative biofuel and bioenergy policy scenarios. 


\section{REFERENCES}

Al-Mansour, F., Zuwala, J., 2010. An evaluation of biomass co-firing in Europe. Biomass and Bioenergy 34, 620-629.

Ando, A.W., Khanna, M., Taheripour, F., 2010. Market and Social Welfare Effect of the Renewable Fuels Standard. in: M. Khanna., J. Scheffran and D. Zilberman (eds.), Handbook of Bioenergy Economics and Policy. Springer Publishers, New York, pp. 233-250.

Beach, R.H., McCarl, B.A., 2010. U.S. Agricultural and forestry Impacts of the Energy Independence and Security Act: FASOM Results and Model Description, Final Report prepared for U.S. Environmental Protection Agency. RTI International, Research Triangle Park, NC

27709. Final Report Prepared for U.S. Environmental Protection Agency, RTI International, Research Triangle Park, NC 27709. Document available online at: http://yosemite.epa.gov/Sab/Sabproduct.nsf/962FFB6750050099852577820072DFDE/\$File/FA $\underline{\text { SOM+Report_EISA_FR.pdf. }}$

Berendt, C.B., 2006. A State-Based Approach to Building a Liquid National Market for Renewable Energy Certificates: The REC-EX Model. The Electricity Journal 19, 54-68. BTS, 2011. Highway-rail Grade Crossings.

Chen, X., Huang, H., Khanna, M., Önal, H., 2014. Alternative Transportation Fuel Standards: Welfare Effects and Climate Benefits. Journal of Environmental Economics and Management 67, 241-257.

Chen, X., Khanna, M., Yeh, S., 2012. Stimulating learning-by-doing in advanced biofuels: effectiveness of alternative policies. Environmental Research Letters 7, 045907.

Chen, X., Önal, H., 2012. Modeling Agricultural Supply Response Using Mathematical Programming and Crop Mixes. American Journal of Agricultural Economics 94, 674-686. 
Chen, X., Önal, H., 2014. An Economic Analysis of the Future U.S. Biofuel Industry, Facility

Location, and Supply Chain Network. Transportation Science 48, 575-591.

Davies, L.L., 2010. Power Forward: The Argument for a National RPS. Connecticut Law

Review 42, 1339-1403.

de Gorter, H., Just, D.R., 2009. The Economics of a Blend Mandate for Biofuels. American

Journal of Agricultural Economics 91, 738-750.

de Witt, M., Junginger, M., Lensink, S., Londo, M., A.Faaij, 2010. Competition between biofuels:

Modeling technological learning and cost reductions over time. Biomass and Bioenergy 34, 203-

217.

Dominguez-Faus, R., Powers, S.E., Burken, J.G., Alvarez, P.J., 2009. The Water Footprint of

Biofuels: A Drink or Drive Issue? Environmental Science \& Technology 43, 3005-3010.

EIA, 2012. Summary Electricity Statistics 1999-2010.

EIA, 2015a. Annual Energy Outlook 2015 with Projections to 2040. U.S. Energy Information

Administration, Office of Integrated Analysis and Forecasting. Washington, DC.

EIA, 2015b. Independent Statistics \& Analysis.

http://www.eia.gov/totalenergy/data/annual/index.cfm.

Fischer, C., 2010. Renewable Portfolio Standards: When Do They Lower Energy Prices? The

Energy Journal 31, 101-120.

Graham, R.L., Nelson, R., Sheehan, J., 2007. Current and Potential U.S. Corn Stover Supplies. Agronomy Journal 99, 1-11.

Hertel, T.W., Tyner, W.E., Birur, D.K., 2010. The Global Impacts of Biofuel Mandates. The Energy Journal 31, 75-100. 
Huang, H., Khanna, M., Önal, H., Chen, X., 2013. Stacking low carbon policies on the renewable fuels standard: Economic and greenhouse gas implications. Energy Policy 56, 5-15. Hudiburg, T.W., Wang, W., Khanna, M., Long, S.P., Dwivedi, P., Parton, W.J., Hartman, M., DeLucia, E.H., 2016. Impacts of a 32-billion-gallon bioenergy landscape on land and fossil fuel use in the US. Nature Energy 1, 15005.

IEA, 2007. Biomass for Power Generation and Combined Heat and Power (CHP).

Jain, A., Khanna, M., Erickson, M., Huang, H., 2010. An Integrated Bio-geochemical and Economic Analysis of Bioenergy Crops in the Midwestern United States. Global Change Biology BioEnergy 2, 258-277.

Lazard, 2014. Lazard's Levelized Cost of Energy Analysis_-Version 8.0. https://www.lazard.com/media/1777/levelized_cost_of_energy_-_version_80.pdf.

Malcolm, S., 2008. Weaning Off Corn: Crop Residues and the Transition to Cellulosic Ethanol, The Transition to A BioEconomy: Environmental and Rural Development Impact, St. Louis, MO. McCarl, B.A., Spreen, T.H., 1980. Price Endogenous Mathematical Programming as a Tool for Policy Analysis. American Journal of Agricultural Economics 62, 87-102.

Mormann, F., 2014a. Beyond Tax Credits - Smarter Tax Policy for a Cleaner, More Democratic Energy Future. Yale Journal on Regulation 31, 304-360.

Mormann, F., 2014b. Re-Allocating Risk: The Case for Closer Integration of Price- and Quantity-Based Support Policies for Clean Energy. The Electricity Journal 27, 9-19.

Nogee, A., Deyette, J., Clemmer, S., 2007. The Projected Impacts of a National Renewable Portfolio Standard. The Electricity Journal 20, 33-47. 
Parker, N., 2012. Spatially Explicit Projection of Biofuel Supply for Meeting Renewable Fuel Standard. Transportation Research Record: Journal of the Transportation Research Board 2287, 72-79.

RFA, 2014. U.S. Fuel Ethanol Industry Plants and Production Capacity.

Schatzki, T., Stavins, R.N., 2012. Implications of Policy Interactions for California's Climate

Policy. http://papers.ssrn.com/sol3/papers.cfm?abstract_id=2296024.

Sebastián, F., Royo, J., Gómez, M., 2011. Cofiring versus biomass-fired power plants: GHG

(Greenhouse Gases) emissions savings comparison by means of LCA (Life Cycle Assessment)

methodology. Energy 36, 2029-2037.

Sheehan, J., Aden, A., Paustian, K., Killian, K., Brenner, J., Walsh, M., Nelson, R., 2003. Energy

and Environmental Aspects of Using Corn Stover for Fuel Ethanol. Journal of Industrial

Ecology 7, 117-146.

Takayama, T., Judge, G., 1971. Spatial and Temporal Price and Allocation Models. Amsterdam-

London: North-Holland Publishing Company.

USDA, 2010. BCAP CHST Summary Report FY 2009 and FY 2010.

USDOE, 2015. BIOENERGY TECHNOLOGIES OFFICE MULTI-YEAR PROGRAM PLAN:

MARCH 2015 in: Energy, U.S.D.o. (Ed.), Washington DC.

Wiser, R., Namovicz, C., Gielecki, M., Smith, R., 2007. The Experience with Renewable

Portfolio Standards in the United States. The Electricity Journal 20, 8-20. 
Table 1- Scope of the agricultural sector.

\begin{tabular}{ll}
\hline Conventional crops & $\begin{array}{l}\text { Corn, Soybeans, Wheat, Rice, Sorghum, Oats, Barley, Cotton, } \\
\text { Peanuts, Potato, Sugarbeet, Sugarcane, Rye, Corn for silage, and } \\
\text { Alfalfa }\end{array}$ \\
\hline Livestock products & Chicken, Turkey, Lamb, Cattle, Hogs, Eggs, Wool, and Milk \\
\hline Processed commodities & $\begin{array}{l}\text { Corn oil, Soybean oil, Peanut oil, Sugar, High fructose corn syrup } \\
\text { (HFCS), Soymeal, Dried Distillers Grains with Solubles (DDGS) }\end{array}$ \\
\hline Cellulosic biomass & $\begin{array}{l}\text { Miscanthus, Switchgrass, Corn stover, Wheat straw, and Forest } \\
\text { residues }\end{array}$ \\
\hline Agricultural production & Western region: Arizona, California, Colorado, Idaho, Montana, \\
regions & Nevada, New Mexico, Oregon, Utah, Washington and Wyoming. \\
& Plains: Nebraska, North Dakota, Oklahoma, South Dakota, Texas \\
& and Kansas; \\
& Midwest: Illinois, Indiana, Iowa, Michigan, Minnesota, Missouri, \\
& Ohio and Wisconsin; \\
South: Alabama, Arkansas, Florida, Georgia, Louisiana, \\
Mississippi and South Carolina; \\
Atlantic: Kentucky, Maryland, New Jersey, New York, North \\
Carolina, Pennsylvania, Tennessee, Virginia, and West Virginia. \\
\hline
\end{tabular}


Table 2- Crop yields and costs of production for biofuel feedstocks in 2007 prices. ${ }^{1}$

\begin{tabular}{|c|c|c|c|c|c|c|}
\hline \multicolumn{2}{|c|}{ Feedstock } & Atlantic & Midwest & Plains & South & West \\
\hline \multirow[t]{2}{*}{$\begin{array}{l}\text { Corn } \\
\text { stover }^{2}\end{array}$} & $\begin{array}{l}\text { Yield } \\
\text { (Mg/ha) }\end{array}$ & $\begin{array}{c}2.60 \\
(2.40-2.90)\end{array}$ & $\begin{array}{c}2.86 \\
(2.40-3.44)\end{array}$ & $\begin{array}{c}2.36 \\
(1.71-3.24)\end{array}$ & $\begin{array}{c}2.50 \\
(1.83-3.03)\end{array}$ & $\begin{array}{c}3.29 \\
(2.25-4.25)\end{array}$ \\
\hline & $\begin{array}{l}\text { Cost } \\
(\$ / \mathrm{Mg})\end{array}$ & $\begin{array}{c}58.35 \\
(45.20- \\
66.72) \\
\end{array}$ & $\begin{array}{c}47.85 \\
(44.53- \\
52.05) \\
\end{array}$ & $\begin{array}{c}41.40 \\
(32.12- \\
49.78) \\
\end{array}$ & $\begin{array}{c}51.92 \\
(41.80- \\
62.46) \\
\end{array}$ & $\begin{array}{c}42.22 \\
(28.94- \\
57.00) \\
\end{array}$ \\
\hline \multirow[t]{2}{*}{$\begin{array}{l}\text { Wheat } \\
\text { straw }^{2}\end{array}$} & $\begin{array}{l}\text { Yield } \\
(\mathrm{Mg} / \mathrm{ha})\end{array}$ & $\begin{array}{c}2.18 \\
(1.96-2.46)\end{array}$ & $\begin{array}{c}2.23 \\
(1.67-2.50)\end{array}$ & $\begin{array}{c}1.42 \\
(1.05-1.67)\end{array}$ & $\begin{array}{c}1.95 \\
(1.74-2.17)\end{array}$ & $\begin{array}{c}2.11 \\
(1.12-4.02)\end{array}$ \\
\hline & $\begin{array}{l}\text { Cost } \\
(\$ / \mathrm{Mg})\end{array}$ & $\begin{array}{c}44.47 \\
(33.88- \\
53.75) \\
\end{array}$ & $\begin{array}{c}35.40 \\
(30.31- \\
40.49) \\
\end{array}$ & $\begin{array}{c}34.04 \\
(28.98- \\
38.37) \\
\end{array}$ & $\begin{array}{c}37.27 \\
(32.75- \\
41.35) \\
\end{array}$ & $\begin{array}{c}32.57 \\
(23.00- \\
44.91) \\
\end{array}$ \\
\hline \multirow[t]{2}{*}{$\begin{array}{l}\text { Switchgrass } \\
\text { (optimistic } \\
\text { scenario) }\end{array}$} & $\begin{array}{l}\text { Yield } \\
\text { (Mg/ha) }\end{array}$ & $\begin{array}{l}12.25 \\
(9.67- \\
13.87) \\
\end{array}$ & $\begin{array}{c}7.53 \\
(5.29- \\
12.62) \\
\end{array}$ & $\begin{array}{c}8.50 \\
(6.86- \\
10.91) \\
\end{array}$ & $\begin{array}{l}11.06 \\
(9.61- \\
11.93) \\
\end{array}$ & NA \\
\hline & $\begin{array}{l}\text { Cost } \\
(\$ / \mathrm{Mg})\end{array}$ & $\begin{array}{c}34.06 \\
(28.49- \\
40.95) \\
\end{array}$ & $\begin{array}{c}40.15 \\
(22.44- \\
54.06)\end{array}$ & $\begin{array}{c}30.02 \\
(25.52- \\
34.43) \\
\end{array}$ & $\begin{array}{c}32.50 \\
(28.25- \\
35.57)\end{array}$ & NA \\
\hline \multirow[t]{2}{*}{$\begin{array}{l}\text { Miscanthus } \\
\text { (optimistic } \\
\text { scenario) }\end{array}$} & $\begin{array}{l}\text { Yield } \\
\text { (Mg/ha) }\end{array}$ & $\begin{array}{c}20.72 \\
(12.90- \\
26.35) \\
\end{array}$ & $\begin{array}{l}14.38 \\
(6.16- \\
21.47) \\
\end{array}$ & $\begin{array}{l}13.85 \\
(6.57- \\
22.16) \\
\end{array}$ & $\begin{array}{l}18.50 \\
(7.31- \\
23.32) \\
\end{array}$ & NA \\
\hline & $\begin{array}{l}\text { Cost } \\
(\$ / \mathrm{Mg})\end{array}$ & $\begin{array}{c}33.44 \\
(26.41- \\
47.05)\end{array}$ & $\begin{array}{c}44.30 \\
(24.80- \\
85.30)\end{array}$ & $\begin{array}{c}41.16 \\
(23.02- \\
67.51)\end{array}$ & $\begin{array}{c}36.58 \\
(27.43- \\
68.16)\end{array}$ & NA \\
\hline \multirow[t]{2}{*}{$\begin{array}{l}\text { Switchgrass } \\
\text { (pessimistic } \\
\text { scenario) }\end{array}$} & $\begin{array}{l}\text { Yield } \\
\text { (Mg/ha) }\end{array}$ & $\begin{array}{l}10.97 \\
(8.66- \\
12.43)\end{array}$ & $\begin{array}{c}6.74 \\
(4.74- \\
11.30)\end{array}$ & $\begin{array}{c}7.61 \\
(6.15-9.77)\end{array}$ & $\begin{array}{c}9.90 \\
(8.60- \\
10.68)\end{array}$ & NA \\
\hline & $\begin{array}{l}\text { Cost } \\
(\$ / \mathrm{Mg})\end{array}$ & $\begin{array}{c}60.78 \\
(46.69- \\
71.27)\end{array}$ & $\begin{array}{c}71.06 \\
(45.56- \\
91.60)\end{array}$ & $\begin{array}{c}59.83 \\
(54.19- \\
65.79)\end{array}$ & $\begin{array}{c}57.89 \\
(47.05- \\
66.99)\end{array}$ & NA \\
\hline \multirow[t]{2}{*}{$\begin{array}{l}\text { Miscanthus } \\
\text { (pessimistic } \\
\text { scenario) }\end{array}$} & $\begin{array}{l}\text { Yield } \\
\text { (Mg/ha) }\end{array}$ & $\begin{array}{l}15.21 \\
(9.46- \\
19.33) \\
\end{array}$ & $\begin{array}{l}10.55 \\
(4.52- \\
15.57) \\
\end{array}$ & $\begin{array}{l}10.16 \\
(4.82- \\
16.26) \\
\end{array}$ & $\begin{array}{c}13.58 \\
(5.36- \\
17.11) \\
\end{array}$ & NA \\
\hline & $\begin{array}{l}\text { Cost } \\
(\$ / \mathrm{Mg})\end{array}$ & $\begin{array}{c}62.96 \\
(44.68- \\
86.61)\end{array}$ & $\begin{array}{c}82.65 \\
(51.45- \\
147.26)\end{array}$ & $\begin{array}{c}80.45 \\
(52.28- \\
123.45)\end{array}$ & $\begin{array}{c}66.91 \\
(47.97- \\
124.00)\end{array}$ & NA \\
\hline
\end{tabular}

Note:

1. Mean is reported in the first row of each cell and range is in parentheses.

2. Crop yields are delivered yields. For corn stover, in addition to a 7\% storage loss, the collection rate is assumed to be $30 \%$ under conventional till and 50\% under conservation till. For wheat straw, we assume a storage loss of $7 \%$ and a collection rate of $50 \%$. For assumptions related to energy crop production, see reference (28) for details.

3.Costs of production are farmgate costs and do not include land rents. 
Table 3- Effects of the US biofuel and bioenergy policies in 2022.

\begin{tabular}{|c|c|c|c|c|}
\hline & No-Policy & $\begin{array}{c}\text { AEO-RFS and } \\
\text { RPS }\end{array}$ & $\begin{array}{c}\text { EISA-RFS and } \\
\text { RPS }\end{array}$ & $\begin{array}{c}\text { Extrapolated } \\
\text { biofuel and } \\
\text { bioenergy policies }\end{array}$ \\
\hline \multicolumn{5}{|c|}{ Land allocation (million ha) and crop prices (\$/MT) } \\
\hline Total cropland use ${ }^{a}$ & 121.2 & 122.7 & 123.1 & 123.6 \\
\hline Food crops & 117.9 & 110.5 & 106.9 & 110.7 \\
\hline Corn for ethanol & 3.3 & 11.9 & 12.0 & 11.8 \\
\hline Energy crops & & 0.3 & 4.2 & 1.2 \\
\hline Regular cropland & & 0.1 & 1.3 & 0.1 \\
\hline Marginal land & & 0.2 & 2.9 & 1.1 \\
\hline Corn stover & & 1.6 & 17.7 & 8.7 \\
\hline Wheat straw & & 0.4 & 8.3 & 1.9 \\
\hline Corn price & 128.1 & 166.4 & 177.3 & 166.4 \\
\hline Soybean price & 324.4 & 391.1 & 413.7 & 386.4 \\
\hline Biomass price & & 67.9 & 91.3 & 78.6 \\
\hline \multicolumn{5}{|c|}{ Mix of cellulosic biomass (million MT) } \\
\hline Total biomass use & & 26.9 & 174.2 & 81.7 \\
\hline Crop residues & & 9.2 & 101.5 & 46.9 \\
\hline Forest residues & & 13.8 & 15.0 & 14.1 \\
\hline Energy crops & & 3.8 & 57.7 & 20.7 \\
\hline Biomass for electricity & & 19.5 & 19.5 & 78.0 \\
\hline Biomass for biofuels & & 7.3 & 154.7 & 3.7 \\
\hline \multicolumn{5}{|c|}{ Mix of biofuels (billion liters) ${ }^{b}$} \\
\hline Total biofuels blended & 18.0 & 64.0 & 136.3 & 62.0 \\
\hline Corn ethanol & 14.7 & 52.7 & 56.8 & 52.0 \\
\hline Cellulosic ethanol & & 2.7 & 56.7 & 1.3 \\
\hline Sugarcane ethanol & 3.3 & 4.8 & 8.0 & 4.8 \\
\hline Biodiesel & & 3.8 & 14.8 & 3.8 \\
\hline \multicolumn{5}{|c|}{ Cellulosic biofuel processing } \\
\hline Number of biorefineries & & 17 & 183 & 9 \\
\hline $\begin{array}{l}\text { Average refinery size } \\
\text { (million liters) }\end{array}$ & & 158 & 310 & 150 \\
\hline \multicolumn{5}{|c|}{ Environmental Impacts $^{c}$} \\
\hline GHGs (Billion MT) & & -0.3 & -0.8 & -0.5 \\
\hline $\begin{array}{l}\text { GHGs abatement per MT of } \\
\text { biomass (MT) }\end{array}$ & & 2.5 & 1.7 & 1.0 \\
\hline $\begin{array}{l}\text { Land use change per } \\
\text { thousand MT of GHG } \\
\text { reduction (ha) }\end{array}$ & & 4.4 & 2.2 & 5.1 \\
\hline
\end{tabular}

Notes: ${ }^{a}$ Total land is the sum of the land allocated to food and biofuel crops; ${ }^{b}$ Ethanol energy equivalent liters; ${ }^{c}$ The numbers presented below represent the changes in GHG emissions (billion MT) aggregated over the period 2007-2022 under biofuel and bioenergy policies relative to a NoPolicy scenario. The GHG emissions under the No-Policy scenario are 34.2 billion MT. 


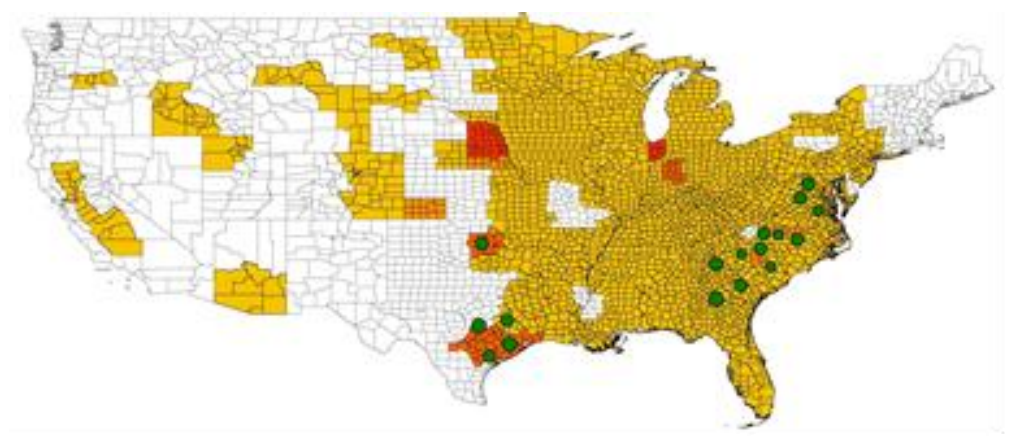

(a) AEO-RFS and RPS

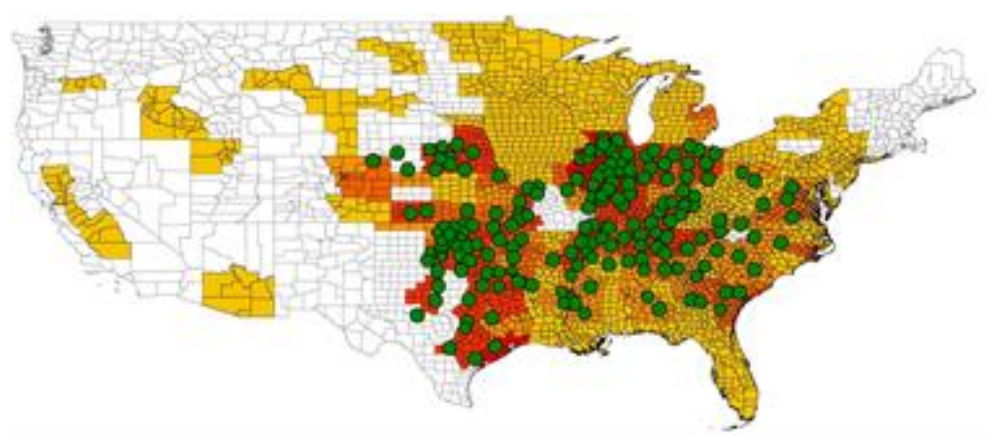

(b) EISA-RFS and RPS

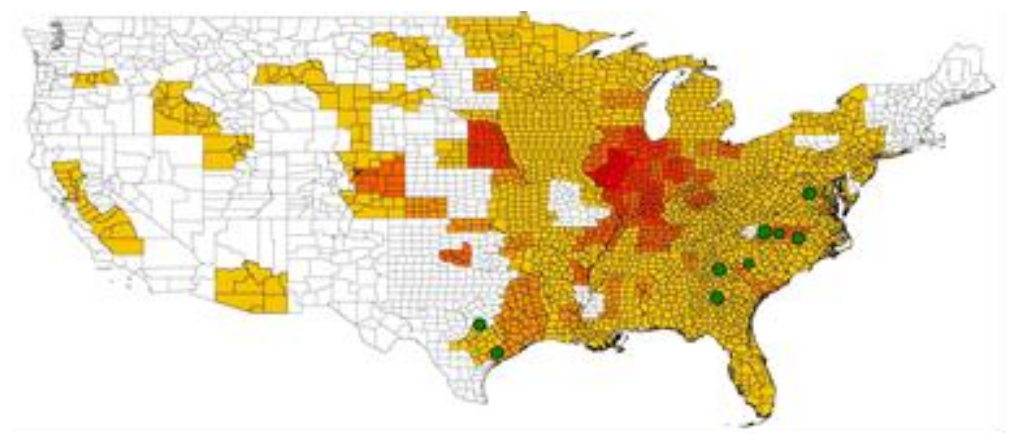

(c) Extrapolated biofuel and bioenergy policies

\section{$1000 \mathrm{MT}$}

$\square 1-290$

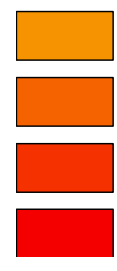

$291-634$

$635-1436$

$1437-2826$

$2827-4773$

\section{Biorefineries}

\section{(million liters)}

○ $1-95$

○ $96-190$

○ $191-285$

○ $286-379$

Fig. 1: Spatial distribution of future cellulosic biorefineries in 2022. 


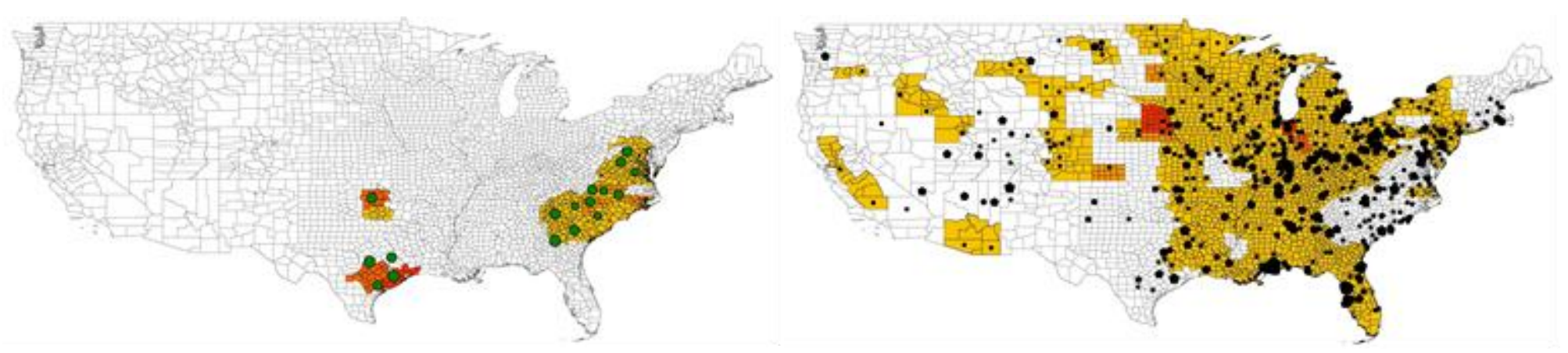

(a) AEO-RFS and RPS

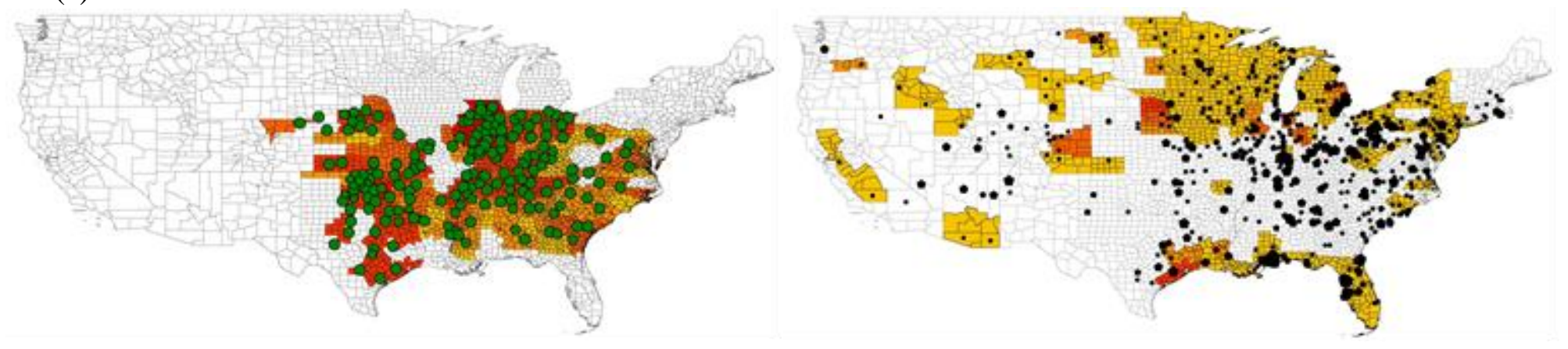

(b) EISA-RFS and RPS

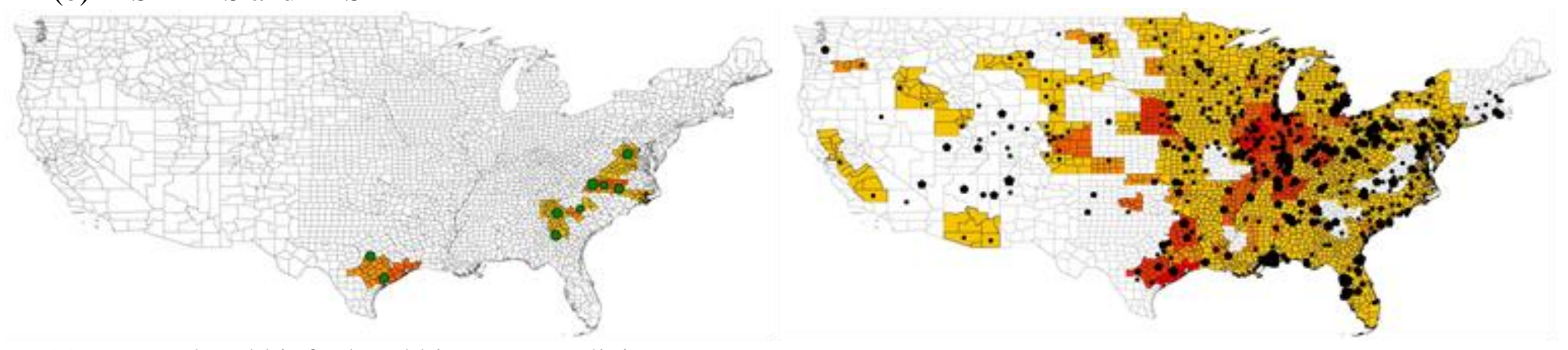

(c) Extrapolated biofuel and bioenergy policies 


\begin{tabular}{|c|c|c|c|}
\hline $\begin{array}{l}1000 \text { MT } \\
\quad 1-290\end{array}$ & $\begin{array}{l}\text { Biorefineries } \\
\text { (million liters) }\end{array}$ & & $\begin{array}{l}\text { wer plants } \\
\text { W) }\end{array}$ \\
\hline $291-634$ & ○ $\quad 1-95$ & $\$$ & $1-884$ \\
\hline $635-1436$ & $96-190$ & $\$$ & $885-1548$ \\
\hline $1437-2826$ & $191-285$ & $\$$ & $1549-246$ \\
\hline $327-4773$ & $286-379$ & $\$$ & $2469-4$ \\
\hline
\end{tabular}

Fig. 2: Regional biomass supply to biorefineries and coal power plants under different biofuel and bioenergy policies in 2022. Note: Figures in the left panel show biomass supply to biorefineries, while figures in the right panel show biomass supply to coalbased power plants 


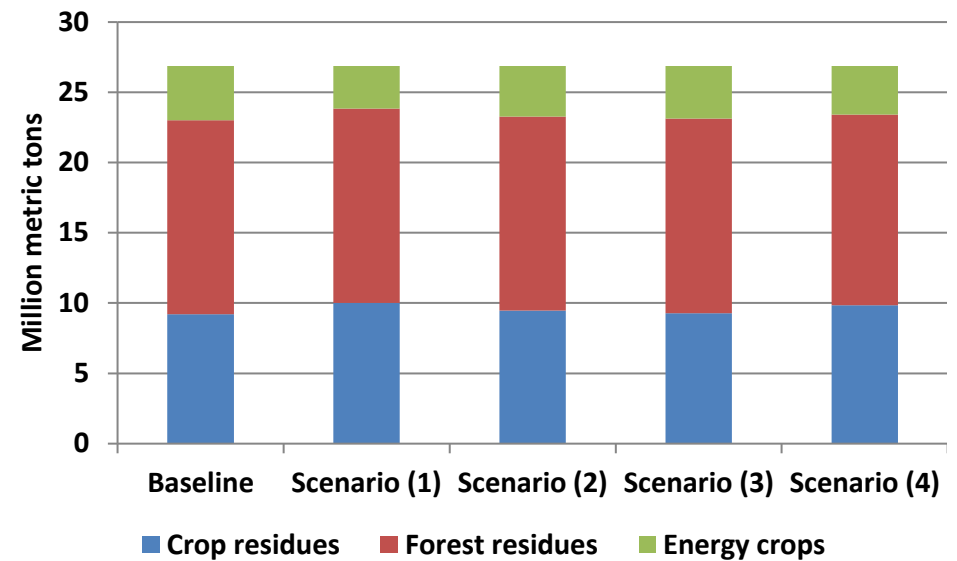

(a) Mix of cellulosic biomass

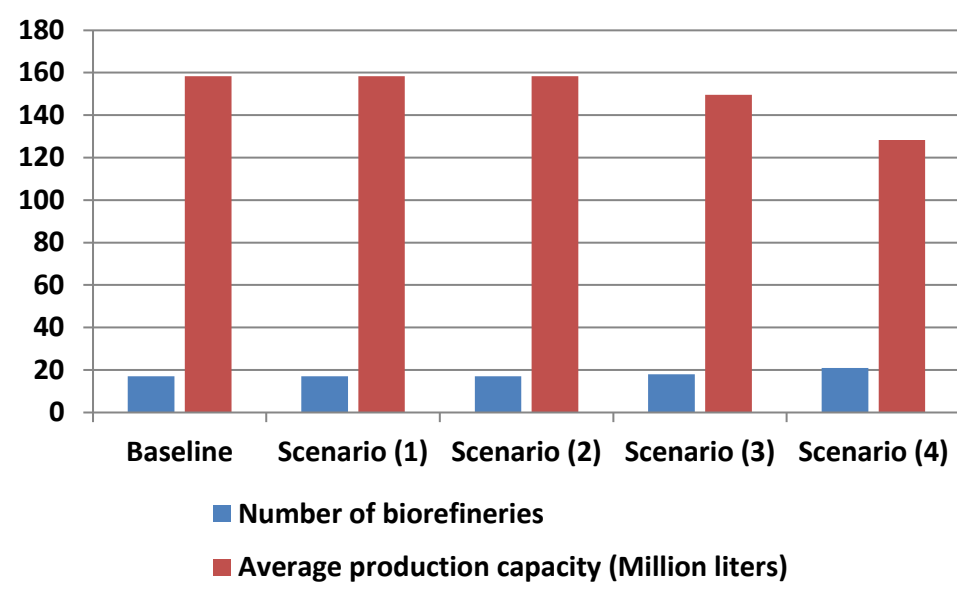

(c) Number and average size of biorefineries

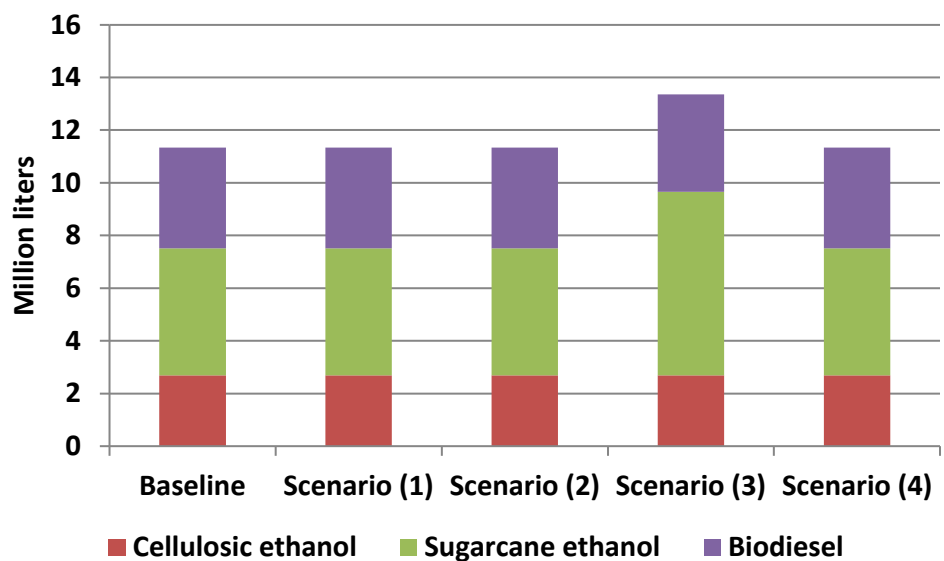

(b) Mix of biofuels

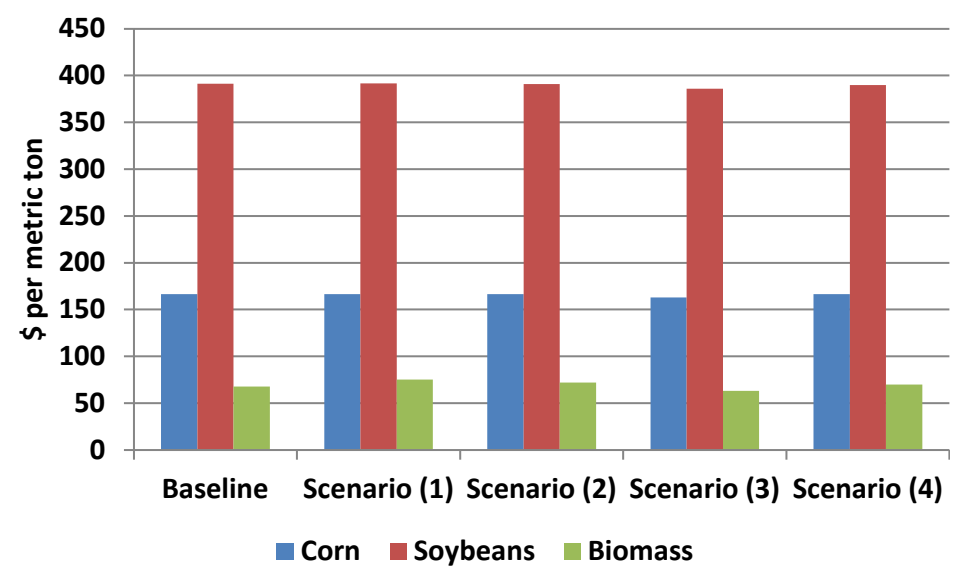

(d) Commodity prices

Fig. 3: Sensitivity analysis for 2022.

All scenarios are simulated under the AEO-RFS and RPS policies. Scenario (1) considers a pessimistic view about the yields and production costs of energy crops; Scenarios (2) changes the upper limit on the amount of land in each county that can be converted to energy crops to $10 \%$. Scenario (3) increases the excess supply elasticity of sugarcane ethanol to 5.0. Scenario (4) increases the unit transportation costs of biomass by $25 \%$. 

Figure captions
\[ \begin{array}{l}\text { Fig. 1: Spatial distribution of future cellulosic biorefineries in } 2022 . \\ \text { Fig. 2: Regional biomass supply to biorefineries and coal power plar } \\ \text { biofuel and bioenergy policies in } 2022 \text {. }\end{array} \]

Fig. 2: Regional biomass supply to biorefineries and coal power plants under different

Figure captions
\[ \begin{array}{l}\text { Fig. 1: Spatial distribution of future cellulc } \\ \text { Fig. 2: Regional biomass supply to biorefin } \\ \text { biofuel and bioenergy policies in } 2022 .\end{array} \]

Fig. 3: Sensitivity analysis for 2022. Figure captions
\[ \begin{array}{l}\text { Fig. 1: Spatial distribution of future cellulc } \\ \text { Fig. 2: Regional biomass supply to biorefin } \\ \text { biofuel and bioenergy policies in } 2022 .\end{array} \]

2.

losic biorefineries in 2022.

a

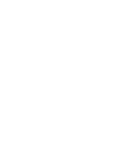

Fig. 3: Sensitivity analysis for 2022.

(n)

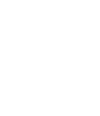

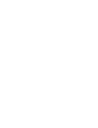

(1)

(1)

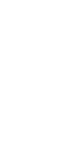

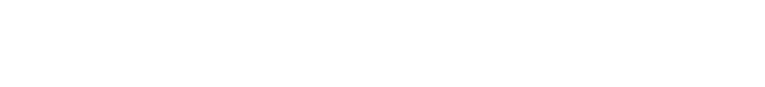

